\title{
KOMUNIKASI TERAPEUTIK ORANG TUA DENGAN \\ ANAK FOBIA SPESIFIK
}

\author{
Rachmaniar \\ Fakultas Ilmu Komunikasi, Universitas Bina Sarana Informatika Bandung
}

\begin{abstract}
ABSTRAK
Penelitian ini dilakukan dalam rangka memahami kesadaran orang tua terhadap masalah anak-anak dengan fobia spesifik, meneliti bagaimana orang tua mengidentifikasi fobia spesifik, memahami tahapan metode yang digunakan untuk mengatasi orang tua anak yang fobia spesifik, dan menjelaskan alasan orang tua menggunakan teknik komunikasi terapeutik untuk mengatasi fobia spesifik anak. Metode yang digunakan dalam penelitian ini adalah pendekatan kualitatif studi kasus. Objek penelitian ini adalah komunikasi terapeutik orang tua. Subyek penelitian adalah lima anak dari orang tua yang memiliki fobia spesifik sebagai sumber informasi utama, yaitu, ibu dari anak-anak fobia spesifik; anak-anak dan kerabat sebagai sumber pendukung informasi. Hasil dari penelitian ini adalah adanya tiga model komunikasi terapeutik orang tua dengan anak fobia spesifik: model pengalaman perwakilan, model pengalaman nyata, dan bermain model pengalaman.
\end{abstract}

Kata-kata kunci: Komunikasi terapeutik, orang tua, anak, fobia spesifik

\section{PARENTS THERAPEUTIC COMMUNICATION WITH CHILDREN WITH SPECIFIC PHOBIAS}

\begin{abstract}
This research purpose is understand parental awareness of children's issues on specific phobias, examines how parents identify specific phobias, understand the stages of the method used by parents to overcome the child's specific phobia, and explain the reasons why parents use therapeutic communication techniques to overcome child's specific phobias. The method used in this research is qualitative case study approach. The object of this research is parent's therapeutic communications. The research subjects are five children who have specific phobias as a main source of information, i.e., mother of the child with specific phobias; children and relatives as an additional of information. The results of this research is the existence of three models of therapeutic communication parents with children with specific phobias: vicarious experience models, real experience models, and playing experience models.
\end{abstract}

Keywords: Therapeutic communication, parents, child, specific phobias

Korespondensi: Rachmaniar, M.I.Kom. Fakultas Ilmu Komunikasi, Universitas Bina Sarana Informatika Bandung, Jl. Sekolah International No. 1-6 Antapani Bandung.Email: seremoniar@gmail.com 


\section{PENDAHULUAN}

Rasa takut berlebih yang dialami seseorang dalam ilmu psikologi dikenal dengan istilah fobia. Fobia atau yang dalam bahasa Yunani disebut dengan phobos, adalah rasa takut berlebih yang terjadi pada seseorang yang berlangsung secara terus-menerus pada suatu objek yang sifatnya irasional.

Rafy (2004) menyatakan bahwa fobia adalah ketakutan yang berlebih-lebihan terhadap benda-benda atau situasi-situasi tertentu yang seringkali tidak beralasan dan tidak berdasarkan pada kenyataan. Fobia adalah rasa ketakutan yang berlebihan pada sesuatu hal atau fenomena.

Kartono (2000) menyebutnya sebagai kekuatan atau kecemasan yang abnormal kuat, tidak rasional, dan tidak bisa dikontrol terhadap suatu situasi atau objek tertentu. Fobia ini kebanyakan terjadi pada masa kanak kanak walaupun dapat juga terjadi pada saat dewasa (Mahendratto, 2007). Menurut para ahli lain, Phobias are relatively common in childhood (Lichtenstein, 2000) dan Interestingly, spesific phobias tend to start during childhood (Davis III, 2012).

Hal ini disebabkan masa kanak-kanak yang merupakan masa dimana anak belajar dari lingkungannya. Orang tua yang berteriak ketika melihat objek tertentu, menunjukkan ekspresi takut yang berlebihan, bahkan melarang anak untuk mendekati objek atau situasi yang ditakuti tersebut tanpa memberikan alasan yang jelas dapat menularkan fobia tersebut pada anakanaknya. Disamping itu karena pengalaman menakutkan yang terjadi secara tiba-tiba yang menyebabkan anak mengalami fobia (Sondang, 2010).

Hal ini membuat timbulnya fobia dengan jenis beragam - coulrophobia (takut badut), pediophobia (takut boneka), anthophobia (takut bunga), achluophobia (takut gelap), ombrophobia (takut hujan), altophobia (takut ketinggian), automysophobia (takut kotor), ailurophobia (takut kucing), thalassophobia (takut laut), agyrophobia (takut menyeberang), xenophobia (takut orang asing), dan lain-lain. Anxiety Disorders Association of America membagi fobia ini dalam tiga kategori, yaitu fobia sosial, fobia kompleks, dan fobia spesifik.

Fobia sosial (fobia terhadap pemaparan situasi sosial) yaitu takut menjadi pusat perhatian, seperti berbicara atau melakukan sesuatu di depan publik, makan di tempat umum, menggunakan toilet umum, atau hampir semua aktivitas lain yang dilakukan di tempat yang terdapat orang lain. Fobia kompleks yaitu fobia terhadap tempat atau situasi ramai dan terbuka, seperti jalan raya, jalan umum, dan lain-lain. Sedangkan fobia spesifik yaitu fobia terhadap suatu objek atau keadaan tertentu seperti pada binatang, tempat tertutup, ketinggian, sekolah, dll

Phobia is characterized by irrational fear of objects, situations and activities resulting in avoidance behaviours. It is a kind of anxiety disorder including social phobia (irrational fear of social situations), agoraphobia (irrational fear of open places), and specific phobia (clinically significant anxiety provoked by exposure of a specific object or situation) (Yihun, 2011).

Dan fobia spesifik menjadi fobia yang paling banyak terjadi pada anak-anak. Along with generalized anxiety disorder (GAD) and separation anxiety disorder $(S A D)$, specific phobias are one of the more commonly diagnosed anxiety disorders in children (McKay, 2011:8).

Studies published in recent years confirm the high prevalence of specific phobias in the general population, especially in children (Bener, 2011).

Untuk itu para psikolog terus mengembangkan metode-metode guna mengatasi masalah fobia spesifik yang terjadi pada anak, diantaranya:

(1) Psikoterapi: dirancang untuk membantu anak belajar cara-cara baru mengontrol ketakutan, kecemasan dan serangan panik jika dan ketika hal tersebut terjadi. Anakanak diajarkan mengatasi fobia dengan menggunakan teknik-teknik seperti self talk - mengingat apakah hal yang ditakutinya tersebut nyata atau bayangan. Ketika rasa takut melanda, anak-anak diminta untuk mengatakan pada dirinya bahwa "Saya OK, saya tidak ada dalam bahaya nyata, ini hanya otak yang menciptakan rasa panik, dan jika saya mengambil napas dalam- 
dalam serta berpikir tenang, perasaan takut akan pergi".

(2) Obat anti-kecemasan: Ketika anak yang mengalami fobia tidak merespon terapi yang dilakukan, terapis dapat memberikan obat anti kecemasan. Hal ini dilakukan guna mendukung pengobatan serta membuat yang mengalami fobia menjadi lebih rileks dan tenang, dan (3) Emotive imagery, play therapy, past-life hypnotic regression, eye movement desensitization and reprocessing, cognitive behavioral therapies (Ginsburg \& Walkup, 2004: 182).

Hal ini menunjukkan bahwa tidak semua metode sesuai bagi anak yang sedang mengalami fobia spesifik karenanya anjuran membawa anak yang mengalami fobia spesifik pada psikolog merupakan anjuran yang tepat, seperti diungkap Fabiola P. Harliamsyah, M.Psi dari Lembaga Terapan Psikologi UI pada Tabloid Nova. Beliau menyatakan bahwa untuk mendapat penanganan yang tepat, maka anak yang mengalami fobia seharusnya dibawa oleh orang tua mereka pada psikolog anak, karena setiap anak adalah unik sehingga setiap penanganan fobia yang terjadi pada anak akan berbeda antara satu anak dengan anak lainnya meski fobianya serupa (Sondang, 2010)

Untuk beberapa kasus, anak yang mengalami fobia spesifik ditangani langsung oleh orang tua mereka tanpa bantuan psikolog. Orang tua berusaha memahami penyebab rasa takut anak, lalu menyusun pesan-pesan, dan menginformasikan pada anak bahwa objek yang ditakuti tersebut bukan sesuatu yang berbahaya, bukan sesuatu yang menyakitkan, dan bukan sesuatu yang layak ditakuti dengan metode mereka sendiri. Selanjutnya orang tua berupaya membawa anak berhadapan langsung dengan objek yang ditakutinya tersebut secara rutin dan berkelanjutan dengan metode-metode tertentu.

Metode yang dilakukan orang tua ini pada dasarnya untuk mengubah pandangan negatif anak tentang objek yang ditakuti tersebut. Metode-metode tersebut terdiri dari kumpulan pesan yang digulirkan secara sengaja, terusmenerus dengan tujuan untuk mengubah pengetahuan, sikap, dan perilaku atas objek yang ditakuti anak - mengatasi masalah fobia spesifik pada anak. Proses penyampaian pesan semacam ini dalam ilmu komunikasi dikenal dengan sebutan komunikasi terapeutik. Terapeutik adalah segala sesuatu yang memfasilitasi proses penyembuhan (Nurjannah, 2005: 1); melakukan atau mengkomunikasikan perkataan, perbuatan, atau ekspresi yang menfasilitasi proses penyembuhan (Titisan, 2011).

Purwanto (1994) menyatakan bahwa komunikasi terapeutik adalah komunikasi yang direncanakan secara sadar, bertujuan dan kegiatannya dipusatkan untuk kesembuhan pasien. Sementara Suryani (2005) menyebutkan bahwa komunikasi terapeutik adalah komunikasi yang dilakukan atau dirancang untuk tujuan terapi dimana seorang penolong atau perawat dapat membantu klien mengatasi masalah yang dihadapinya melalui komunikasi. Pada kasus ini, pendekatan yang dilakukan orang tua memosisikan orang tua sebagai penolong, anak sebagai klien atau pasien yang dibantu masalah fobia spesifik, dan komunikasi terapeutik sebagai proses yang terjadi didalamnya.

Penggunaan metode yang dilakukan orang tua dalam mengatasi fobia spesifik pada anak tanpa bantuan psikolog menyebabkan penulis tertarik untuk memahami bagaimana penggunaan komunikasi terapeutik orang tua dalam mengatasi fobia spesifik pada anak dengan pendekatan yang dibuatnya sendiri (self treatment).

Rumusan masalah dalam penelitian ini yaitu: (1) Bagaimana kesadaran orang tua pada masalah anak fobia spesifik? (2) Bagaimana cara orang tua mengidentifikasi anak terkena fobia spesifik? (3) Bagaimana tahapan metode yang digunakan orang tua untuk mengatasi anak fobia spesifik?, dan (4) Mengapa orang tua menggunakan teknik komunikasi terapeutik untuk mengatasi anak fobia spesifik?

Berdasarkan latar belakang yang telah diuraikan, maka penelitian ini menggunakan pendekatan studi kasus dengan tujuan untuk: (1) Memahami kesadaran orang tua pada anak masalah fobia spesifik, (2) Menelaah cara orang tua mengidentifikasi anak fobia spesifik, (3) Memahami tahapan metode yang digunakan orang tua untuk mengatasi anak fobia spesifik, dan (4) Menjelaskan alasan orang tua menggunakan teknik komunikasi terapeutik untuk mengatasi anak fobia spesifik.

Manfaat dari penelitian ini secara teoritis diharapkan dapat menambah kajian teoritis dalam bidang komunikasi antarpribadi pada umumnya, dan komunikasi terapeutik pada khususnya, serta secara praktis penelitian ini 
diharapkan dapat membantu para orang tua mengatasi fobia spesifik pada anak dengan penggunaan komunikasi terapeutik.

\section{KAJIAN LITERATUR}

Terapeutik menurut As Hornby (1974) adalah kata sifat yang dihubungkan dengan seni penyembuhan - segala sesuatu yang menfasilitasi proses penyembuhan (Nurjannah, 2005:1). Seseorang yang melakukan terapeutik, seseorang tersebut sedang mengkomunikasikan perkataan, perbuatan, atau ekspresi untuk menfasilitasi proses penyembuhan.

Komunikasi terapeutik adalah komunikasi yang direncanakan secara sadar, bertujuan, dan kegiatannya dipusatkan untuk kesembuhan pasien; mengacu pada pendekatan yang direncanakan secara sadar, bertujuan, dan dengan kegiatan yang terpusat. Carl Rogers (1961) menyebutnya dengan bagaimana seseorang melakukan komunikasi tersebut dengan orang lain, bukan tentang apa yang dilakukan seseorang, dan ini membuat Rogers berhasil mengidentifikasi tiga factor dasar dalam mengembangkan hubungan saling membantu (helping relationship): pembantu harus benarbenar ikhlas dan memahami tentang dirinya atau keikhlasan (genuineness), pembantu harus menunjukan rasa empati, individu yang dibantu harus merasa bebas untuk mengeluarkan segala sesuatunya tentang dirinya dalam menjalin hubungan atau kehangatan (warmth) (Mundakir, 2006:119), dan ini mencakup unsur komunikasi berikut: (1) sumber komunikasi yaitu pengirim pesan atau sering disebut komunikator yaitu orang yang menyampaikan atau menyiapkan pesan. Komunikator dalam hal ini adalah orangtua yang membantu anak mengatasi fobia spesifiknya. Komunikator memiliki peran untuk membentuk kesamaan persepsi dengan pihak lain, untuk kasus ini adalah anak fobia spesifik. Kemampuan komunikator mencakup keahliaan atau kredibilitas daya tarik dan keterpercayaan menjadi faktor penting dan berpengaruh terhadap keberhasilan komunikasi ( Tan, 1981:104). (2) Unsur komunikasi terapeutik selain komunikator, yaitu pesan merupakan salah satu unsur penting yang harus ada dalam proses komunikasi . Tanpa kehadiran pesan, proses komunikasi tidak terjadi. Komunikasi akan berhasil bila pesan disampaikan dengan tepat, dapat dimengerti, dan dapat diterima komunikan. Moore menyebut keberhasilan komunikasi sangat ditentukan oleh daya tarik pesan (Rakhmat, 1998:297). Sementara Onong Effendy dalam buku Ilmu Teori dan Filsafat Komunikasi menyatakan bahwa komunikasi akan berhasil bila pesan yang disampaikan memenuhi syarat berikut: a) pesan direncanakan, b) pesan menggunakan bahasa yang dapat dimengerti kedua belah pihak, c) pesan menarik minat dan kebutuhan pribadi penerima, dan d) pesan berisi hal-hal yang mudah dipahami.

Komunikasi orangtua pada anak fobia spesifik bertujuan mengubah sikap dan perilaku anak fobia spesifik - menyembuhkan anak fobia spesifik - komunikasi terapeutik dengan memperhatikan kemampuan orangtua untuk menyampaikan pesan serta bagaimana pengemasan pesan tersebut diciptakan orangtua.

Dalam komunikasi terapeutik pada anak, Mahmud Machfoedz pada buku Komunikasi Keperawatan menyebut hal-hal yang harus diperhatikan pada anak ketika terapeutik: (1) Nada suara - tempo bicara rendah, memperlambat pembicaraan, tidak mendesak - menunjang komunikasi efektif dengan anak. (2) Mengalihkan perhatian - anak tertarik pada aktivitas yang disukai; perlu dibuat jadwal agar aktivitas yang disukai diprogramkan dan dapat diatur waktunya. (3) Jarak interaksi - perhatian jarak yang sesuai ketika berinteraksi dengan anak. (4) Marah - perlu mempelajari isyarat kontrol perilaku pada anak untuk menghindari kemarahan anak; tidak bersuara keras dan bersikap otoriter; mengurangi kontak mata ketika respon meningkat. Jika respon mulai terkendali, kontak mata dapat dilakukan, namun komunikasi melalui sentuhan ditunda terlebih dahulu. (5) Kesadaran diri - selalu memberikan motivasi dan persetujuan jika diperlukan. (6) Sentuhan - berjabat tangan dapat menghilangkan stres dan cemas pada anak.

Terdapat banyak teknik komunikasi terapeutik verbal maupun nonverbal yang dapat diterapkan pada anak saat terapeutik. Teknik komunikasi terapeutik nonverbal diantaranya adalah: (1) Teknik orang ketiga - teknik ini berusaha mengungkapkan ekspresi orang ketiga, seperti "dia atau mereka." (2) Bercerita - menggunakan bahasa anak, sekaligus menyelidiki perasaan; berusaha menghindari hambatan yang disengaja - meminta anak 
menceritakan pengalamannya secara spesifik saat berada di rumah sakit. (3) Tiga Permintaan (Three Wishes) - merupakan suatu strategi yang digunakan untuk mengundang anak-anak masuk dalam sebuah percakapan.

Sedangkan teknik komunikasi terapeutik verbal diantaranya adalah: (1) Menulis merupakan alternative yang digunakan untuk melakukan pendekatan komunikasi dengan anak. (2) Menggambar - merupakan bentuk komunikasi yang berharga melalui pengamatan gambar. (3) Teknik bermain - merupakan bentuk komunikasi yang paling penting dan menjadi teknik yang efektif untuk bisa berhubungan dan berkomunikasi dengan anak (Mundakir, 2006 : 154).

Evelyn Millis Duvall dalam buku Marriage and Family Development menyebut bahwa orang tua adalah orang yang berperan pada pengasuhan anak untuk meningkatkan perkembangan fisik, mental, emosional, dan sosialnya; orang tua memberikan perawatan fisik dan perhatian emosional serta mengarahkan perkembangan kepribadian anak.

Sementara Yupi Supartini dalam buku Konsep Dasar Keperawatan Anak menyatakan bahwa tujuan pengasuhan anak adalah untuk mempertahankan perkembangan fisik anak, meningkatkan kesehatan anak, memfasilitasi anak untuk mengembangkan kemampuannya sejalan dengan tahap pertumbuhan dan perkembangannya yang mendorong peningkatan kemampuan berperilaku sesuai dengan nilai agama dan budaya yang diyakini. Kemampuan orang tua untuk menjalankan peran pengasuhan ini tidak dapat dipelajari secara formal, tetapi harus berdasarkan pengalaman yang dilaluinya serta pengalaman orangtua lain yang sudah lebih dulu menjalani peran sebagai orangtua.

Marilyn M. Friedman dalam buku Keperawatan Keluarga menyebutnya sebagai guru yang utama karena orang tua menginterpretasikan dunia masyarakat bagi anak-anak. Lingkungan seperti kekuatankekuatan dari luar merupakan hal penting bagi orang tua untuk menuntun anak berpikir menerjemahkan arti-arti penting yang dimiliki lingkungan (kekuatan-kekuatan luar).

Hal-hal yang ditakuti anak fobia spesifik - objek-objek yang dirisaukan anak fobia spesifik merupakan lingkuangan luar yang memilki kekuatan besar yang mempengaruhi jiwa anak fobia spesifik, dan orangtua menjadi guru utama untuk menerjemahkan keberadaan objek-objek tersebut, serta menuntun anak fobia spesifik agar berpikir rasional dan logis dalam menanggapi keberadaan objek-objek yang ditakutinya tersebut.

Phobia berasal dari bahasa Yunani "phobos", yang berarti obyek atau situasi yang ditakuti (dari nama dewa Yunani yang menakutkan musuh-musuhnya).

Phobia adalah ketakutan yang berlebih-lebihan terhadap benda-benda atau situasi-situasi tertentu yang seringkali tidak beralasan dan tidak berdasar pada kenyataan.

Baker Encyclopedia of Psychology and Counseling menyebutnya dengan obyek atau situasi-situasi yang tidak berbahaya; ketakutan, gamang, perasaan takut yang tak terkendalikan terhadap situasi yang seringkali tanpa alasan yang dapat diterima oleh akal (Sudarsono, 1996:179-180); ketakutan yang menetap dan tidak rasional terhadap suatu obyek, aktivitas atau situasi yang spesifik, yang menimbulkan suatu keinginan mendesak atau menghindarinya (Hawari, 2007:64); reaksi ketakutan yang hebat (abnormal) terhadap situasi atau benda yang khusus (Semiun, 2006:323); rasa takut yang kuat dan menetap serta tidak sesuai dengan stimulus, tidak rasional bahkan bagi si penderita sendiri, yang menyebabkan penghindaran objek maupun situasi yang ditakuti tersebut (Tomb, 2000:100).

Ivan Ward dalam buku Phobia menyebutnya dengan ketakutan yang tidak masuk akal. Kaplan, Sadock, dan Greb dalam buku Sinopsis Psikiatri Ilmu Pengetahuan Psiatri Klinis menyatakannya dengan ketakutan irasional yang perlu dihidari, ketakutan yang memiliki ratusan macam kasus.

Dalam penelitian ini, anak-anak yang penulis temui memiliki ketakutan berlebih pada objek-objek yang tidak menakutkan - irasional. Ketakutan ini sifatnya sangat kuat, menetap, dan konsisten tertuju pada objek tersebut.

Menurut Anxiety Disorders Association of America, fobia dibagi dalam tiga jenis, yaitu: (1) Fobia sosial adalah ketakutan menetap dan tidak rasional yang umumnya berkaitan dengan keberadaan orang lain (Davison \& Neale, 2006:185). Individu yang menderita fobia sosial biasanya mencoba menghindari situasi di mana ia mungkin dinilai dan menunjukkan tanda-tanda kecemasan atau berperilaku secara memalukan. 
Ketakutan yang ditunjukkan dengan keringat berlebihan atau memerahnya wajah merupakan hal jamak. Berbicara atau melakukan sesuatu di depan public, makan di tempat umum, menggunakan toilet umum, atau hampir semua aktivitas lain yang dilakukan di tempat yang terdapat orang lain dapat menimbulkan kecemasan ekstrem, bahkan serangan panik (Davison \& Neale., 2006:186). Fobia jenis ini biasanya si penderita akan mengalami kecemasan yang berlebihan jika berhadapan dengan situasi sosial atau menghadapinya dengan penuh tekanan. Keadaan yang sering memicu terjadinya kecemasan pada penderita fobia social, adalah: berbicara di depan umum, tampil di depan umum, makan di depan orang lain. Jenis fobia sosial yang lebih umum ditandai dengan kecemasan pada situasi sosial. penderita fobia sosial menyeluruh biasanya merasa bahwa penampilannya tidak sesuai dengan yang diharapkan, mereka akan merasa terhina atau dipermalukan. (2) Agoraphobia (takut berada di tempat terbuka atau pusat keramaian) didefinisikan oleh American Psychiatric Association sebagai rasa takut berada di tempat atau situasi, ketika meloloskan diri dianggap sulit atau memalukan, atau ketika pertolongan mungkin tidak diperoleh jika ia mengalami serangan panik atau gejala mirip panik. Fobia jenis ini biasanya si penderita ketakutan berada di tempat terbuka yang banyak orang, seperti mal dan pasar dan berada dalam situasi dimanapun secara fisik dan psikologis merasa kesulitan melarikan diri atau sulit mendapat pertolongan segera saat mendapat serangan. Mereka umumnya jadi takut bepergian, menghindar dari kendaraan, atau pergi ke pasar. (3) Fobia spesifik adalah ketakutan yang beralasan yang disebabkan oleh kehadiran atau antisipasi suatu objek atau situasi spesifik. Lebih ringkasnya fobia ini disebabkan oleh obyek atau situasi spesifik. Fobia jenis ini merupakan jenis fobia yang sering terjadi. Contoh dari fobia ini misalnya takut pada binatang, takut pada ketinggian dan sebagainya. Penderita fobia spesifik biasanya mengatasi ketakutannya dengan cara menghindari benda atau keadaan yang membuatnya takut. Menurut American Psychiatric Association, fobia spesifik dibagi dalam lima jenis: tipe fobia terhadap binatang ( tikus, anjing atau binatang berbulu lebat ), tipe lingkungan alam (ketinggian, kilat atau air), tipe fobia terhadap darah, suntikan, atau luka, tipe situasional ( berada dalam pesawat terbang, lift, atau tempat tertutup ), tipe lainnya ( ketakutan terhadap kostum karakter tertentu pada anakanak ) dengan kriteria untuk pengidap fobia spesifik adalah adanya rasa takut yang persisten, berlebihan dan tanpa alasan terhadap objek atau situasi tertentu, serta adanya respon secara tibatiba terhadap stimulus atau rangsangan yang ditakuti. Ketakutan tersebut terlalu berlebihan atau tanpa alasan, menghindar dari situasi atau keadaan yang menimbulkan ketakutan tersebut, dan fobia tersebut berhubungan dengan fungsi normal lainnya atau menyebabkan stress.

Dalam penelitian ini, anak-anak yang penulis temui memiliki fobia spesifik - ketakutan berlebih pada satu objek tertentu (ketakutan terhadap kostum karakter tertentu pada anakanak), persisten, dan segera menghindar jika bertemu objek yang ditakutinya tersebut.

W. F. Maramis menjelaskan diantara gejala-gejala atau simptom-simptom fobia adalah rasa takut yang diderita oleh klien dapat mengakibatkan perasaan seperti akan pingsan, rasa lelah, palpitasi, berkeringat, mual, tremor, dan panik. (Maramis, 1994: 267)

Ginsburg dan Walkup menyebut anakanak yang mengalami fobia spesifik akan menderita diam-diam ; mengamuk, menangis, dan menjadi agresif untuk melarikan diri dari situasi ketika dihadapkan dengan objek yang ditakutinya (Ginsburg \& Walkup, 2004: 176).

American Psychiatric Association merinci menjadi: perasaan teror, panik, horor, atau ketakutan; pemahaman diri bahwa rasa takut melampaui bahaya yang sebenarnya; ketakutan yang begitu ekstrem sehingga mengganggu pikiran dan tindakan; gejala fisik seperti rasa sesak napas, jantung berdetak cepat atau gemetar.

Dalam penelitian ini, anak-anak yang penulis temui memiliki beberapa gejala seperti yang disebutkan diatas saat bertemu dengan objek yang ditakutinya tersebut - jantung berdetak cepat, menangis, berkeringat, atau panic.

Orangtua yang berteriak ketika melihat objek tertentu, menunjukkan ekspresi takut yang berlebihan, bahkan melarang anak untuk mendekati objek atau situasi yang ditakuti tersebut tanpa memberikan alasan yang jelas dapat menularkan fobia tersebut pada anakanaknya.

Anxiety and fear can be inherited. Just as 
a child can inherit a parent's brown hair, green eyes and nearsightedness, a child can also inherit that parent's tendency toward excessive anxiety. In addition, anxiety may be learned from family members and others who are noticeably stressed or anxious around a child. For example, a child whose parent shows immense fear of spiders may learn to fear spiders, too.

Disamping itu karena pengalaman menakutkan yang terjadi secara tiba-tiba yang menyebabkan anak mengalami fobia.

A traumatic experience (such as a divorce, illness or death in the family) or even just a major life event like the start of a new school year may also trigger the onset of an anxiety disorder.

Individuals who have been attacked by a dog may develop a specific phobia disorder and become conditioned to fear dogs.

Para psikolog terus mengembangkan metodemetode guna mengatasi masalah fobia yang terjadi pada anak: (1) Psikoterapi: dirancang untuk membantu anak belajar cara-cara baru mengontrol ketakutan, kecemasan dan serangan panik jika dan ketika hal tersebut terjadi. Seorang terapis akan mengajarkan anak bagaimana mengatasi fobia dengan menggunakan berbagai teknik seperti berlatih self-talk untuk mengingat apa hal tersebut nyata atau bayangan (misalnya, Saya OK. Saya mungkin merasa seperti akan mati karena saya sangat takut, tapi itu hanya otak saya yang menciptakan panik. Saya tidak ada dalam bahaya nyata. Jika saya mengambil napas dalam-dalam dan berpikir dengan tenang, perasaan ini akan pergi). (2) Obat anti-kecemasan: Jika anak yang fobia tidak merespon terapi, terapis dapat menambahkan obat anti kecemasan dalam rencana pengobatan. Obat-obat ini dapat sangat bermanfaat membantu anak menjadi lebih rileks ketika dihadapkan pada pemecahan masalah dan keterampilan mengatasi ketakutannya pada saat terapi berlangsung. (3) Konseling: konselor biasanya akan mendengarkan permasalahan seseorang, seperti ketakutannya saat berhadapan dengan barang atau situasi yang membuatnya fobia. Setelah itu konselor akan memberikan cara untuk mengatasinya. (4) Desensitization: atau secara bertahap penderita fobia dihadapkan pada situasi atau obyek yang membuatnya takut. Kemudian terapis akan melakukan komunikasi dengan penderita untuk mengubah pola pikir sekaligus meningkatkan kepercayaan diri penderita. (5) Hipnoterapi: atau otak seseorang distimulus agar otak orang tersebut dalam keadaan trance (gelombang otak beta pada saat itu berkurang, yang aktif adalah gelombang alfa dan beta). Hipnoterapis akan berperan mengendalikan pikiran orang tersebut untuk membantunya menemukan jalan pikiran, perasaannya, hingga mampu memengaruhi tindakan orang tersebut guna membantunya mengatasi problema. (5) Pendekatan Cognitive Behaviour: yaitu suatu konseling yang akan menggali pikiran, perasaan dan perilaku seseorang dalam rangka mengembangkan caracara praktif yang efektif untuk melawan fobia.

Dalam penelitian ini, anak-anak yang penulis temui diatasi langsung permasalahan fobianya oleh orangtua mereka, dan dapat disembuhkan hingga tidak mengalami ketakutan berlebih pada objek yang sebelumnya ditakuti

Ciri-ciri normal (tidak fobia): (1) Fungsi Psikologis: dimana seseorang mampu untuk menjalani peran atau fungsi dalam kehidupannya atau kesehariannya, meliputi aspek kognitif, afektif dan psikomotor. Kognitif: Seseorang tidak mempunyai kecemasan terhadap objek tertentu, dalam situasi tertentu dan saat bertemu objek tertentu, menyebabkan seseorang tidak menghindari situasi yang ada di sekitarnya. Apabila seseorang berada pada situasi-situasi tersebut maka seseorang akan merasa biasa saja. Afektif: ketika seseorang berada dalam situasi atau posisi yang membuatnya mengalami kecemasan, seseorang tetap nyaman dan tidak merasa telah membuat keanehan. Psikomotor: seseorang tidak gemetar, tangannya tidak berkeringat, dan jantungnya tidak berdebar kencang ketika bertemu dengan objek tertentu atau situasi tertentu. (2) Pairment: seseorang tidak menunjukan pada keadaan dimana ia merusak dirinya baik secara fisik ataupun psikologis. Secara fisik: ketika seseorang mengalami perasaan tidak cemas, orang tersebut tidak akan kehilangan atau kelebihan berat badan dalam waktu yang cepat (semula kehilangan $15 \mathrm{~kg}$ kemudian dengan cepat memperoleh $25 \mathrm{~kg}$ ), tidak akan mengalami kurang tidur dengan sering terbangun di pagi hari, tidak akan kelelahan saat siang hari, dan tidak akan mengalami kesulitan berkonsentrasi. Secara psikologis: karena tidak lagi mengalami kecemasan, seseorang tidak akan merasa tertekan, pemalu, pendiam, atau gugup ketika 
bertemu dengan objek atau situasi yang ditakutinya. (3) Respon Actipical: merupakan sesuatu yang diharapkan terkait dengan budaya. Seseorang yang merasa takut dan cemas ketika berhadapan dengan objek atau situasi tertentu, ini merupakan sesuatu yang tidak sesuai dengan budaya pada umumnya, karena tidak mungkin terus-menerus menghindar bertemu dengan suatu objek atau situasi terntentu.Seseorang merasa gemetar, tangannya berkeringat, jantungnya berdebar lebih kencang ketika berhadapan dengan objek atau situasi tertentu, ini juga tidak sesuai dengan budaya sebab jika bagaimanapun objek atau situasi tertentu adalah sesuatu yang tidak dapat dihindari.

Interaksi simbolik berasal dari kata "interaksi" dan "simbolik". Interaksi berarti proses saling mempengaruhi dalam bentuk perilaku atau kegiatan di antara anggotaanggota masyarakat (Effendy, 1989: 184); hal yang saling melakukan aksi, berhubungan, mempengaruhi; antarhubungan (Kam, 2001: 438). Sementara simbolik berarti bersifat melambangkan sesuatu (Effendy, 1989: 352); sebagai lambang, menjadi lambang, mengenai lambang (Kam, 2001: 1066).

Interaksi simbolik berarti segala hal yang saling berhubungan dengan pembentukan makna dari suatu benda atau lambang atau simbol, baik benda mati atau hidup, melalui proses komunikasi baik verbal atau non verbal, dengan tujuan akhir memaknai lambang atau simbol (objek) tersebut berdasarkan kesepakatan bersama yang berlaku di wilayah atau kelompok komunitas masyarakat tertentu. Douglas (1970) menyebut makna tersebut berasal dari interaksi, dan tidak ada cara lain untuk membentuk makna, selain dengan membangun hubungan dengan individu lain melalui interaksi (Ardianto dan Q-Anees, 2007: 136).

Ralph Larossa dan Donald C. Reitzes (1993) meyatakan bahwa interaksi simbolik sebagai kerangka referensi untuk memahami bagaimana manusia, bersama dengan orang lain, menciptakan dunia simbolik dan bagaimana cara dunia membentuk perilaku manusia (West dan Turner, 2008: 96).

Menekankan bahwa manusia dalam proses saling menterjemahkan, dan saling mendefinisikan tindakannya, tidak dibuat secara langsung antara stimulus-response, tetapi didasari pada pemahaman makna yang diberikan terhadap tindakan orang lain melalui penggunaan simbol-simbol, interpretasi, dan pada akhirnya tiap individu tersebut akan berusaha saling memahami maksud dan tindakan masingmasing, untuk mencapai kesepakatan bersama; menyatakan bahwa manusia atau individu hidup dalam suatu lingkungan yang dipenuhi oleh simbol-simbol. Tiap individu memberikan tanggapan terhadap simbol-simbol yang ada - penilaian individu menanggapi suatu rangsangan (stimulus) dari suatu yang bersifat fisik.

Pemahaman individu terhadap simbolsimbol merupakan hasil pembelajaran dalam berinteraksi di tengah masyarakat, dengan cara mengkomunikasikan simbol-simbol yang ada disekitar mereka, baik secara verbal maupun non verbal.

Emory A. Griffin dalam buku A First Look at Communication Theory menyebut bahwa Herbert Blumer dan George Herbert Mead sebagai yang pertama-tama mendefinisikan teori symbolic interactionism.

Mead memfokuskan pada isyarat non verbal dan makna dari suatu pesan verbal, akan mempengaruhi pikiran orang yang sedang berinteraksi.

Dalam terminologi Mead, setiap isyarat non verbal (seperti body language, gerak fisik, baju, status, dll) dan pesan verbal (seperti katakata, suara, dll) yang dimaknai berdasarkan kesepakatan bersama oleh semua pihak yang terlibat dalam suatu interaksi merupakan satu bentuk simbol yang mempunyai arti yang sangat penting (a significant symbol).

Stephen W. Littlejohn dan Karen A. Foss dalam buku Teori Komunikasi menyebut bahwa teori sibenertika menekankan hubungan timbale balik di antara semua bagian dari sebuah sistem; pelaku komunikasi banyak berbagi dengan sosiopsikologis, keduanya terfokus pada sistem kognitif individu - sebuah susunan keyakinan, sikap, serta nilai yang kompleks serta saling berinteraksi yang memengaruhi dan dipengaruhi oleh perilaku.

Pikiran seseorang sebuah sistem yang mengambil input dari lingkungan dalam bentuk informasi, dalam bentuk pesan-pesan yang dikirimkan; pikiran bekerja atau memproses berdasarkan informasi tersebut dan selanjutnya menciptakan perilaku-perilaku yang kemudian memengaruhi semua hal di sekitar orang tersebut. 
Ada salah satu genre terkait teori sibenertika, yaitu teori penggabungan informasi.

Pendekatan penggabungan informasi (information-integration) bagi pelaku komunikasi berpusat pada seseorang mengakumulasi dan mengatur informasi tentang semua orang, objek, situasi, dan gagasan yang membentuk sikap atau kecenderungan untuk bertindak dengan cara yang positif atau negative terhadap beberapa objek; menawarkan untuk menjelaskan pembentukan informasi dan perubahan sikap.

Model ini bermula dengan konsep kognisi yang digambarkan sebagai sebuah kekuatan sistem interaksi.

Informasi adalah salah satu dari kekuatan tersebut dan berpotensi untuk memengaruhi sebuah sistem kepercayaan atau sikap individu. Sebuah sikap dianggap sebagai sebuah akumulasi dari informasi tentang sebuah objek, seseorang, situasi, atau pengalaman.

Dua variable yang memiliki peranan penting dalam memengaruhi perubahan sikap, pertama adalah valence atau arahan. Valence mengacu pada apakah informasi mendukung keyakinan seseorang atau menyangkal mereka. Ketika informasi menyokong keyakinan seseorang, maka informasi tersebut mempunyai valence "positif". Ketika tidak menyokong, maka valence "negative"

Variabel kedua yang memengaruhi dampak dari informasi adalah bobot - sebuah kegunaan dari kredibilitas. Jika seseorang berpikir bahwa informasi tersebut adalah benar, maka seseorang akan memberikan bobot yang lebih tinggi pada informasi tersebut; jika tidak, maka seseorang akan memberikan bobot yang lebih rendah.

Perubahan sikap terjadi karena informasi baru yang muncul dalam keyakinan, menyebabkan adanya perubahan dalam sikap atau karena informasi yang baru mengubah bobot atau valence pada sebuah informasi. Jadi, valence memengaruhi bagaimana informasi memengaruhi sistem keyakinan seseorang dan bobot memengaruhi seberapa banyak pengaruh itu bekerja.

\section{METODE PENELITIAN}

Penelitian ini adalah penelitian dengan menggunakan paradigma konstruktivis, pendekatan kualitatif dengan tradisi penelitian studi kasus. Konstruktivisme merupakan paradigma yang bertolak belakang dengan positivisme. Positivisme memandang subjek (manusia) dan objek komunikasi sebagai dua hal terpisah, konstruktivisme memandang manusia dan objek penelitian sebagai satu kesatuan menganggap manusia merupakan bentuk objek penelitian.

Elvinaro Ardianto dan Bambang Q-Anees dalam buku Filsafat Ilmu Komunikasi tahun 2007 menyebut subjek memiliki kemampuan control terhadap maksud-maksud tertentu pada setiap wacana. Komunikasi dipahami, diatur, dan dihidupkan oleh pernyataanpernyataan yang bertujuan - setiap pernyataan adalah tindakan penciptaan makna - tindakan pembentukan diri serta pengungkapan jati diri sang pembicara.

Semesta merupakan proses konstruksi sosial - keterkaitan antara pikiran manusia dengan semesta dibentuk melalui wacanawacana yang berkembang dalam pikiran manusia, menghasilkan makna jamak (multiple reality) dalam memahami satu fenomena menghasilkan beragam makna yang terbentuk dalam pikiran manusia.

Dalam kerangka paradigma penelitian, Denzim dan Lincoln pada buku Handbook of Qualitative Research memaparkan tiga landasan filosofis bagi paradigma konstruktivisme sebagai paradigma penelitian: (1) Ontologi: Relativis. Realitas bisa dipahami dalam bentuk konstruksi mental yang bermacam-macam yang tak dapat diindra, didasarkan pada sosial dan pengalaman, berciri local dan spesifik, bentuk serta isi tergantung pada manusia atau kelompok indvidual yang memiliki konstruksi tersebut. Pada pengertian mutlak, konstruksi mental tidak kurang atau lebih "benar", tetapi sekedar lebih atau kurang dan atau canggih. Konstruksi dapat diubah sebagaimana "realitas" ikutannya demikian. (2) Epistemologi: Transaksional dan subjektivis. Penulis dan objek penelitian dianggap terhubung - timbale balik sehingga "hasil-hasil penelitian" tercipta secara literal seiring dengan berjalannya proses penelitian. Perbedaan konvensional antara ontology dengan epistemology lenyap, sebagaimana yang terjadi dalam teori kritis. (3) Metodologi: Hermeneutis dan Dialektis. Sifat variable dan personal dari konstruksi sosial menunjukkan bahwa konstruksi individu hanya dapat diciptakan dan disempurnakan melalui interaksi antara dan di antara penulis dengan para responden. 
Beragam konstruksi diinterpretasikan menggunakan teknik-teknik hermeneutic konvensional dan dikomparasikan serta diperbandingkan melalui pertukaran dialektis dengan tujuan akhir mendapatkan sebuah konstruksi consensus yang lebih matang dan canggih daripada semua konstruksi sebelumnya.

Sementara penelitian kualitatif adalah penelitian yang bersifat empiris (dapat diamati dengan pancaindera sesuai dengan kenyataan), dengan pengamatan atas data tidak didasarkan pada ukuran-ukuran matematis yang terlebih dulu ditetapkan peneliti dan harus disepakati (direplikasi) oleh pengamatan lain, tetapi berdasarkan ungkapan subjek penelitian, sebagaimana yang dikehendaki dan dimaknai oleh subjek penelitian. Pendekatan kualitatif menggunakan konsep kealamiahan (kecermatan, kelengkapan, atau orisinalitas) data dan apa yang sebenarnya terjadi di lapangan.

Pendekatan kualitatif terutama layak untuk menelaah sikap atau perilaku dalam lingkungan yang agak artifisial, seperti dalam survei atau eksperimen. Peneliti kualitatif lebih menekankan proses dan makna ketimbang kuantitas, frekuensi atau intensitas (yang secara matematis dapat diukur), meskipun peneliti tidak mengharamkan statistik deskriptif dalam bentuk distribusi frekuensi atau presentase untuk melengkapi analisis datanya (Mulyana \& Solatun, 2007: 11).

Lalu untuk tradisi penelitian studi kasus adalah penelitian dimana peneliti menggali suatu fenomena tertentu (kasus) dalam suatu waktu dan kegiatan (program, even, proses, institusi atau kelompok sosial) serta mengumpulkan informasi secara terinci dan mendalam dengan menggunakan berbagai prosedur pengumpulan data selama periode tertentu.

Studi kasus adalah sebuah eksplorasi dari "suatu sistem yang terikat" atau suatu kasus (beragam kasus) yang dari waktu ke waktu melalui pengumpulan data yang mendalam serta melibatkan berbagai sumber informasi yang "kaya" dalam suatu konteks. Sistem terikat ini diikat oleh waktu dan tempat sedangkan kasus dapat dikaji dari suatu program, peristiwa, aktivitas atau suatu individu (Creswell, 1997: 61).

John W. Creswell dalam buku Qualitative Inquiry And Research Design menyatakan bahwa fokus studi kasus adalah spesifikasi kasus dalam suatu kejadian baik itu yang mencakup individu, kelompok budaya, ataupun suatu potret kehidupan.

Penelitian ini berfokus pada kejadian yang terjadi pada individu dengan kasus yang spesifik - komunikasi terapeutik orangtua pada anak fobia spesifik.

Lebih lanjut Creswell mengemukakan beberapa karakteristik dari suatu studi kasus yaitu : (1) mengidentifikasi "kasus" untuk suatu studi. Kasus yang diangkat dalam penelitian ini untuk studi komunikasi; (2) Kasus tersebut merupakan sebuah "sistem yang terikat" oleh waktu dan tempat. Kasus dalam penelitian ini berlangsung pada tahun 2012 di Bandung; (3) Studi kasus menggunakan berbagai sumber informasi dalam pengumpulan datanya untuk memberikan gambaran secara terinci dan mendalam tentang respons dari suatu peristiwa dan (4) Menggunakan pendekatan studi kasus, peneliti akan "menghabiskan waktu" dalam menggambarkan konteks atau setting untuk suatu kasus. Kasus dalam penelitian ini memiliki berbagai sumber informasi - orangtua, anak, serta kerabat lain yang tinggal bersama keluarga. Untuk penelitian ini, penulis sudah memiliki informasi ada yang sejak tahun 2011 lalu, dan ada yang sejak tahun 2012 lalu.

Berdasarkan paparan di atas, dapat diungkapkan bahwa studi kasus adalah sebuah eksplorasi dari "suatu sistem yang terikat" atau "suatu kasus/beragam kasus" yang dari waktu ke waktu melalui pengumpulan data yang mendalam serta melibatkan berbagai sumber informasi yang "kaya" dalam suatu konteks. Sistem terikat ini diikat oleh waktu dan tempat sedangkan kasus dapat dikaji dari suatu program, peristiwa, aktivitas atau suatu individu. Dengan perkataan lain, studi kasus merupakan penelitian dimana peneliti menggali suatu fenomena tertentu (kasus) dalam suatu waktu dan kegiatan (program, even, proses, institusi atau kelompok sosial) serta mengumpulkan informasi secara terinci dan mendalam dengan menggunakan berbagai prosedur pengumpulan data selama periode tertentu.

Selanjutnya Creswell mengungkapkan bahwa apabila kita akan memilih studi untuk suatu kasus seyogyanya menggunakan berbagai sumber informasi. Konteks kasus dapat "mensituasikan" kasus di dalam settingnya yang terdiri dari setting fisik maupun setting sosial, sejarah atau setting ekonomi. Sedangkan fokus di dalam suatu kasus dapat dilihat dari 
keunikannya, memerlukan suatu studi (studi kasus intrinsik) atau dapat pula menjadi suatu isu (isu-isu) dengan menggunakan kasus sebagai instrumen untuk menggambarkan isu tersebut (studi kasus instrumental). Ketika suatu kasus diteliti lebih dari satu kasus hendaknya mengacu pada studi kasus kolektif .

Penelitian ini memiliki fokus pada studi kasus intrinsic, kasus dilihat dari keunikannya, dimana masalah fobia spesifik pada anak diselesaikan oleh orangtua bukan oleh psikolog

Menurut Creswell, pendekatan studi kasus lebih disukai untuk penelitian kualitatif. Untuk itu Creswell menyarankan bahwa peneliti yang akan mengembangkan penelitian studi kasus hendaknya pertama-tama, mempertimbangan tipe kasus yang paling tepat. Kasus tersebut dapat merupakan suatu kasus tunggal atau kolektif, banyak tempat atau di dalam tempat, berfokus pada suatu kasus atau suatu isu (intrinsikinstrumental). Penelitian ini merupakan kasus tunggal, yaitu fobia spesifik yang terjadi pada tempat tertentu dengan berfokus pada suatu kasus.

Kedua, dalam memilih kasus yang akan diteliti dapat dikaji dari berbagai aspek seperti beragam perspektif dalam permasalahannya, proses atau peristiwa. Ataupun dapat dipilih dari kasus biasa, kasus yang dapat diakses atau kasus yang tidak biasa. Penelitian ini mengkaji proses komunikasi terapeutik orangtua yang dilakukan pada anak fobia spesifik, dan hal ini merupakan kasus yang dapat diakses.

Lebih lanjut Creswell mengemukakan beberapa "tantangan" dalam perkembangan studi kasus kualitatif sebagai berikut: (1) Peneliti hendaknya dapat mengidentifikasi kasusnya dengan baik; (2) Peneliti hendaknya mempertimbangkan apakah akan mempelajari sebuah kasus tunggal atau multikasus; (3) Dalam memilih suatu kasus diperlukan dasar pemikiran dari peneliti untuk melakukan strategi sampling yang baik sehingga dapat pula mengumpulkan informasi tentang kasus dengan baik pula; (4) Memiliki banyak informasi untuk menggambarkan secara mendalam suatu kasus tertentu; (5) Dalam merancang sebuah studi kasus, peneliti dapat mengembangkan sebuah matriks pengumpulan data dengan berbagai informasi yang dikumpulkan mengenai suatu kasus; (6) Memutuskan "batasan" sebuah kasus. Batasan-batasan tersebut dapat dilihat dari aspek waktu, peristiwa, dan proses. adalah penelitian dimana peneliti menggali suatu fenomena tertentu (kasus) dalam suatu waktu dan kegiatan (program, even, proses, institusi atau kelompok sosial) serta mengumpulkan informasi secara terinci dan mendalam dengan menggunakan berbagai prosedur pengumpulan data selama periode tertentu.

Dalam penelitian ini, yang menjadi subjek penelitian adalah orangtua yang memiliki anak fobia spesifik sebagai sumber informasi utama, yaitu ibu dari anak-anak fobia spesifik - Wik, $\mathrm{Na}$, Jeng, Rah, dan Is; serta anak dan kerabat sebagai sumber informasi pendukung.

Anak, yaitu anak-anak yang mengalami fobia spesifik kostum karakter - Gel, Nar, Gem, Ir, dan Del; serta kerabat sebagai sumber informasi pendukung, yaitu yang mengetahui tahapan metode - terlibat dalam komunikasi terapeutik yang dilakukan orangtua terhadap anak fobia spesifik - $\mathrm{Ca}, \mathrm{Yu}$, Ham, dan Na, dengan pengambilan sampel secara bertujuan (purposive sampling).

Lalu untuk triangulasi sumber, untuk memperkaya data yang diperoleh, penulis mewawancarai seorang psikolog anak yang memahami kasus fobia spesifik - Yunita Sari, M.Psi.

Objek dari penelitian ini adalah hal-hal yang berkaitan dengan kemampuan orangtua mengatasi fobia spesifik pada anak melalui komunikasi terapeutik, serta tahap-tahap penyelesaiannya, dan alasan orangtua (ayah atau ibu) untuk menangani kasus tersebut tanpa bantuan psikolog anak. Hal ini tentu akan menjelaskan kemampuan orangtua (ayah atau ibu) secara verbal dan non verbal dalam menyampaikan pesan-pesan tersebut pada anak serta bagaimana pengemasan pesan tersebut diciptakan orangtua.

Penelitian akan dilaksanakan pada keluarga yang memiliki anak fobia spesifik di Bandung - Cigereleng, Buahbatu, Kopo, dan Cikarees dengan menggunakan subjek manusia sebagai instrumen utama. Penulis melakukan wawancara mendalam dengan orang tua dan kerabat yang mengetahui masalah penelitian ini, observasi partisipatif pasif dan juga studi literatur. (1) Wawancara - penulis melakukan wawancara mendalam dengan orangtua dan jika ada kerabat yang mengetahui masalah penelitian ini. Wawancara mendalam adalah wawancara tidak terstruktur yang dilakukan 
secara instensif, kualitatif, dan secara terbuka serta bersifat luwes juga susunan pertanyaan dan susunan kata-kata dalam setiap pertanyaan dapat diubah pada saat wawancara sesuai dengan kebutuhan dan kondisi saat wawancara. (2) Observasi Partisipatif Pasif - penulis melakukan observasi partisipatif pasif dengan berusaha melihat respon anak fobia spesifik pada objek yang ditakutinya. Observasi partisipatif pasif adalah suatu bentuk observasi khusus dimana peneliti tidak terlibat dalam kegiatan tersebut. Peneliti hanya menjadi pengamat dan tidak mengambil peran dalam situasi tertentu, atau tidak berpartisipasi dalam peristiwa-peristiwa yang sudah terjadi tersebut. (3) Studi Literatur - penulis melakukan studi literatur dengan maksud mendapatkan gambaran yang menyeluruh tentang apa yang sudah dikerjakan orang lain dan bagaimana orang mengerjakannya, kemudian melihat perbedaan penelitian yang akan dilakukan. Studi literatur yang dilakukan penulis antara lain berdasarkan buku, jurnal, serta artikel blog dari para akademisi.

Dari hasil wawancara mendalam dengan orangtua dan jika ada kerabat yang mengetahui masalah penelitian ini, juga berdasarkan hasil observasi partisipatif pasif dilapangan ditambah studi literatur berdasarkan buku, jurnal, serta artikel blog dari para akademisi, maka peneliti melakukan proses analisis data dengan cara mereduksi data. Proses reduksi data yang dilakukan peneliti meliputi memilih data, menyaring data, mengkode data serta menajamkan data yang kemudian membuat abstraksi. Abstraksi merupakan usaha membuat rangkuman yang inti, proses, dan pernyataanpernyataan yang perlu dijaga sehingga tetap berada didalamnya (Moleong, 1999:190).

Setelah melakukan reduksi data maka peneliti mencoba untuk menyajikan data dengan membuat tabel, bagan atau grafik. Kemudian setelah proses penyajian data maka proses terakhir adalah penarikan kesimpulan.

Analisis data merupakan bagian terpenting dalam penelitian. Data yang dikumpulkan akan bermakna dan berguna dalam menjawab permasalahan penelitian jika diolah dan dianalisis. Creswell berasumsi bahwa analisis data merupakan proses berkelanjutan yang membutuhkan refleksi terus-menerus terhadap data, mengajukan pertanyaan-pertanyaan analitis dan menulis catatan singkat sepanjang penelitian.

Dalam penelitian apapun dan siapapun penelitinya menginginkan data yang mampu dipertanggungjawabkan, karena keabsahan data bersifat krusial dalam peneitian kualitatif. Untuk menentukan keabsahan data maka ada beberapa teknik yang bisa digunakan seperti realibilitas, validitas, dan generalisabilitas.

Untuk menguji keabsahan data dalam penelitian ini, maka digunakan teknik validitas dengan pendekatan triangulasi. Triangulasi bisa diartikan sebagai usaha untuk mengecek kebenaran data atau informasi yang diperoleh penulis dari berbagai sudut pandang yang berbeda dengan cara mengurangi sebanyak mungkin bias yang terjadi pada saat pengumpulan dan analisis data. Menurut Patton triangulasi dibedakan menjadi beberapa jenis, yaitu, triangulasi data (disebut juga triangulasi sumber), triangulasi metode, triangulasi teori, dan triangulasi peneliti (Pawito, 99:2007). Dari empat jenis triangulasi di atas, penulis menggunakan pendekatan triangulasi metode dan triangulasi data. Triangulasi metode menuntut penulis untuk membandingkan temuan data dari hasil catatan lapangan selama observasi partisipatif pasif dengan hasil transkip atau rekaman dari wawancara mendalam mengenai komunikasi terapeutik orangtua dan anak fobia spesifik. Sementara triangulasi data menuntut penulis untuk menggunakan berbagai sumber data seperti dokumen, arsip, hasil wawancara, hasil observasi, atau juga dengan mewawancarai lebih dari satu subjek yang dianggap memiliki sudut pandang berbeda. Alasan penulis menguji keabsahan data dengan pendekatan triangulasi adalah untuk mengetahui fenomena tunggal yang sedang berlangsung dari sudut pandang yang berbeda-beda dan memungkinkan mendapatkan kebenaran yang bisa dipertanggungjawabkan serta mengurangi bias dan subjektivitas. Sebagaimana diketahui penulis merupakan instrumen utama dalam penelitian kualitatif, sehingga sulit terhindar dari bias dan subjektivitas.

Menurut Moleong setiap penelitian memerlukan uji keabsahan data atau uji validitas dan pemeriksaan terhadap keabsahan data mutlak dilakukan sehingga penelitian tersebut benar-benar dapat dipertanggungjawabkan dari segala segi. Sedangkan menurut Creswell menyatakan bahwa validitas data merupakan 
kekuatan lain dalam penelitian kualitatif selain reliabilitas.

Dalam buku Qualitative Inquiry And Research Design karya John W. Creswell, Asmussen dan Creswell mencoba mengkaji studi kasus kualitatif melalui laporan kasus substantif dari Lincoln \& Guba. Format Lincoln \& Guba ini dimulai dengan : (1) membuktikan penjelasan masalah, sebuah deskripsi yang terinci mengenai konteks atau setting serta proses yang diamati, sebuah diskusi tentang elemen penting dan pada akhirnya menyusun hasil penelitian melalui "pelajaran yang dipelajari". (2) setelah memperkenalkan studi kasus dengan masalah tertentu, kemudian penulis memberikan deskripsi secara terinci mengenai setting dan kronologis tentang masalah tersebut. Kemudian beralih kepada tema penting yang muncul dalam analisis. (3) mengumpulkan data melalui berbagai macam teknik pengumpulan data. (4) naratif menggambarkan peristiwa dengan menghubungkan konteks pada bingkai kerja yang lebih luas. (5) melakukan verifikasi kasus dengan menggunakan beberapa sumber data untuk suatu tema melalui triangulasi dan pengecekkan anggota.

\section{HASIL DAN PEMBAHASAN}

Wik - orang tua Gel mengaku menyadari Gel terkena fobia saat menyaksikan program acara kesehatan di televisi. Saat itu ditampilkan secara jelas bagaimana respon penderita fobia terhadap badut sebagai objek yang ditakutinya - persis dengan yang dialami Gel. Sementara Jeng - orang tua Gem mengaku menyadari Gem terkena fobia setelah berdiskusi dengan saya - sebelumnya Jeng membahas fobia yang dialami saudaranya serupa dengan fobia yang dialami vokalis band favoritnya (Korn). Lalu $\mathrm{Na}$ - orang tua Nar mengaku hanya mengetahui Nar terkena fobia, tidak mengerti definisi fobia; Rah dan Is sama sekali tidak menyadari Ir dan Del terkena fobia.
Maramis (1994) menjelaskan diantara gejala-gejala atau symptoms fobia adalah rasa takut yang diderita oleh klien dapat mengakibatkan perasaan seperti akan pingsan, rasa lelah, palpitasi, berkeringat, mual, tremor, dan panik - gejala tersebut mirip dengan gejala yang dialami oleh Gel dan Nar ketika akan atau bertemu dengan objek yang ditakutinya tersebut.

Sementara Ginsburg dan Walkup menyebut anak-anak yang mengalami fobia spesifik akan menderita diam-diam; mengamuk, menangis, dan menjadi agresif untuk melarikan diri dari situasi ketika dihadapkan dengan objek yang ditakutinya (Ginsburg \& Walkup, 2004: 176) - Gem, Ir, dan Del mengalami gejala serupa seperti yang disebutkan diatas.

Kelima anak fobia spesifik tersebut cenderung mudah diidentifikasi rasa takutnya lewat bahasa nonverbal mereka. Sementara untuk konsistensi anak terhadap objek yang ditakutinya-kelima orang tua menjawab serupa, anak-anak secara konsisten takut terhadap objek-objek tersebut. Seperti dikatakan oleh Hawari (2007) Fobia adalah ketakutan yang menetap dan tidak rasional terhadap suatu objek, aktivitas atau situasi yang spesifik, yang menimbulkan suatu keinginan mendesak atau menghindarinya.

Lalu untuk wujud dari objek yang ditakuti anak fobia spesifik, kelima orang tua memiliki jawaban beragam.

Baker Encyclopedia of Psychology and Counseling (1999) menyebut fobia sebagai ketakutan terhadap objek atau situasi-situasi yang tidak berbahaya.

Wik - orang tua Gel menyebutnya dengan ketakutan yang berlebihan "lebay", Jeng orang tua Gem menyebutnya sebagai ketakutan yang tidak layak ditakuti.

Pada tahapan metode orang tua mengatasi anak fobia spesifik, Wik menggunakan media videoclip dalam treatment nya dan mengganti kata badut dengan boneka orang.

Tabel 1 Gambaran Singkat Anak Fobia Spesifik

\begin{tabular}{cccccc}
\hline No & Nama & Jenis Kelamin & Fobia Spesifik & Awal Fobia & Usia 2013 \\
\hline 1 & Gel & Perempuan & Badut & 2011 & 5 tahun \\
2 & Nar & Perempuan & Dokter & 2011 & 4 tahun \\
3 & Gem & Laki-laki & Polisi & 2012 & 4 tahun \\
4 & Ir & Perempuan & Penganten & 2011 & 4 tahun \\
5 & Del & Perempuan & Silverman & 2011 & 5 tahun \\
\hline
\end{tabular}


Tabel 2 Wujud Objek Yang Ditakuti Anak Fobia Spesifik

\begin{tabular}{|c|c|c|c|c|c|}
\hline No & Nama & Gejala Fobia & $\begin{array}{l}\text { Konsistensi } \\
\text { pada Objek }\end{array}$ & $\begin{array}{l}\text { Wujud } \\
\text { Objek }\end{array}$ & Akibat \\
\hline 1 & Gel & $\begin{array}{c}\text { muka cemas, } \\
\text { berkeringat }\end{array}$ & konsisten & $\begin{array}{c}\text { beragam - seram, tidak } \\
\text { seram }\end{array}$ & $\begin{array}{c}\text { menolak pergi ke } \\
\text { mall }\end{array}$ \\
\hline 2 & Nar & sakit perut & konsisten & $\begin{array}{c}\text { beragam - ramah, tidak } \\
\text { ramah }\end{array}$ & $\begin{array}{c}\text { menolak pergi ke } \\
\text { dokter }\end{array}$ \\
\hline 3 & Gem & Mengamuk & konsisten & biasa & menolak pergi jauh \\
\hline 4 & Ir & $\begin{array}{l}\text { menangis, } \\
\text { menjerit-jerit }\end{array}$ & konsisten & cantik & $\begin{array}{c}\text { menolak datang ke } \\
\text { undangan }\end{array}$ \\
\hline 5 & Del & $\begin{array}{l}\text { mengamuk, } \\
\text { menangis, marah }\end{array}$ & konsisten & lucu & $\begin{array}{l}\text { menolak lewat } \\
\text { setopan }\end{array}$ \\
\hline
\end{tabular}

Memiliki pengalaman melihat badut tanpa kepala badutnya.

$\mathrm{Na}$ menggunakan media orang (dokter asli) dalam treatmentnya dan membiasakan diri menggunakan baju - blazer, kemeja warna putih.

Menyebut dokter dengan sebutan "teman Teh $\mathrm{Ca}$, guru Teh Ca"; dan melakukan kontak khusus dengan dokter meminta dokter memberi Nar kue ketika akan menyuntik.

Jeng menggunakan media lagu dan buku cerita dalam treatmentnya, dan melibatkan Nay (adik Gem) dalam treatment tersebut mengkomunikasikan seakan-akan adik tidak takut polisi.

Rah menggunakan media orang (penganten asli) dalam treatmentnya dan memperkenalkan Ir dengan tata rias - make up salon.

Memajang foto pernikahan berukuran besar di rumah dan menekankan pada Ir bahwa di tempat resepsi tersedia banyak makanan - es krim, baso tahu, dan lain-lain.

spidol dan pewarna kuku perak dalam treatmentnya, dan melibatkan Kakak Del $(\mathrm{Na})$ untuk bermain bersama Del dengan mediamedia tersebut.

Alasan orang tua menggunakan teknik

\title{
Tabel 3 Tahapan Metode Orang tua Gel (Fobia Badut)
}

\author{
Tahapan Metode
}

Tahap Awal Mengatasi Anak Fobia Spesifik

1. Memperhatikan kesukaan Gel

2. Mencari videoclip lagu yang sesuai dengan fobia Gel

3. Memutar lagu berkali-kali tanpa memutar videoclipnya

4. Gel menyukai lagu tersebut

Tahap Pertengahan Mengatasi Anak Fobia Spesifik

5. Memutar lagu dengan memutar videoclipnya

6. Gel melihat videoclip tersebut, dan tidak takut dengan badut

7. Orang tua (ibu) tidak berkomentar - diam

8. Ibu berbicara pada adik bahwa yang ada dalam videoclip tersebut boneka orang (badut)

9. Ibu menegaskan bahwa boneka orang tersebut lucu Ibu menegaskan bahwa ibu dapat seperti itu jika memakai kostum tersebut

Tahap Akhir Mengatasi Anak Fobia Spesifik

10. Videoclip diputar terus-menerus, dan setiap kemunculan badut, ibu dan adik serempak (nada tertentu) menyebut boneka orang

11. Ada pengalaman tidak disengaja melihat badut tanpa kepala - ibu dan adik serempak menyebut boneka orang

12. Gel menyadari bahwa kostum badut berisikan orang

13. Gel tidak menolak diajak ke mall besar Selalu menyebut badut dengan sebutan boneka orang 
Tabel 4 Tahapan Metode Orang tua Nar (Fobia Dokter)

Tahapan Metode

\section{Tahap Awal Mengatasi Anak Fobia Spesifik}

1. Nar bertemu kerabat ( $\mathrm{Ca}$ - dokter) saat sakit

2. Nar diperiksa dirumah $\mathrm{Ca}$; $\mathrm{Ca}$ menyambut dengan ramah; Ca menggunakan piyama, dan Nar tidak takut

3. Orang tua dan Nar menemui Ca di puskesmas; Ca menyambut dengan ramah; Ca tidak menggunakan jas dokter, dan Nar tidak takut

\section{Tahap Pertengahan Mengatasi Anak Fobia Spesifik}

4. Nar dan keluarga kerap menggunakan pakaian putih - baju, celana, blazer, dan dress putih

5. Orang tua dan Nar menemui Ca di klinik; Ca menyambut dengan ramah; Ca tidak menggunakan jas dokter; Ca menggunakan baju putih, dan Nar tidak takut

6. Orang tua dan Nar menemui Ca di klinik; Ca menyambut dengan ramah; $\mathrm{Ca}$ menggunakan jas dokter, dan Nar tidak takut

Tahap Akhir Mengatasi Anak Fobia Spesifik

7. Ibu menyebut dokter dengan sebutan teman Teh $\mathrm{Ca}$ (dokter muda), dan guru Teh $\mathrm{Ca}$ (dokter senior)

8. Ibu menginformasikan pada Nar bahwa orang-orang yang ada di klinik dan rumah sakit adalah teman $\mathrm{Teh} \mathrm{Ca}$ dan guru Teh $\mathrm{Ca}$

9. Orang tua dan Nar menemui teman-teman $\mathrm{Ca}$ di klinik; teman-teman Ca menyambut dengan ramah; teman-teman Ca menggunakan jas dokter, dan Nar tidak takut

komunikasi terapeutik tertentu pada anak fobia spesifik adalah (1) Wik dengan videoclip lagu memiliki alasan karena Gel menyukai lagu - mencari videoclip yang sesuai dengan fobia Gel (badut). (2) Na menggunakan media orang (dokter asli) dalam treatment karena pengalaman bertemu $\mathrm{Ca}$ yang membuat Nar tidak dipenuhi rasa takut seperti sebelumnya. $\mathrm{Na}$ penasaran untuk melakukan treatment selanjutnya. (3) Jeng dengan bercerita lewat videoclip dan buku cerita memiliki alasan untuk menarik perhatian Gem - fokus ibu tetap pada anak; mencari sesuatu yang ringan, sederhana, dan tidak membebani Gem. (4) Rah menyatakan bahwa alasan menggunakan treatment ini karena coba-coba, berdasar pengalaman yang tidak disengaja, membuat Rah ingin mencoba treatment ini pada penganten yang lain., dan (5) Is mengaku bahwa treatment yang dilakukannya didapat dari seorang teman, dan merasa tidak ada salahnya untuk mempraktekkan itu pada Del.

\section{Tabel 5 Tahapan Metode Orang tua Gema (Fobia Polisi)}

Tahapan Metode

\section{Tahap Awal Mengatasi Anak Fobia Spesifik}

1. Orang tua (ibu) menemukan videoclip lagu yang sesuai dengan fobia anak; ibu membeli buku cerita yang sesuai dengan fobia anak

2. Ibu menceritakan isi lagu pada adik; ibu menceritakan isi buku cerita pada adik - tugas polisi (mengatur jalan, membatu orang menyeberang jalan) dan ucapan terimakasih pada polisi

$$
\text { Tahap Pertengahan Mengatasi Anak Fobia Spesifik }
$$

3. Gem memperhatikan cerita ibu

4. Ibu fokus - serius bercerita pada adik

Tahap Akhir Mengatasi Anak Fobia Spesifik

5. Ibu berkali-kali bercerita pada adik; Gem terbiasa mendengar cerita polisi

6. Setiap melihat polisi, ibu tidak berkomentar; ibu menyebut, "Alhamdulillah, hebat" saat melihat polisi mengatur jalan 
Tabel 6 Tahapan Metode Orang tua Irma (Fobia Penganten)

\begin{tabular}{|c|}
\hline Tahapan Metode \\
\hline Tahap Awal Mengatasi Anak Fobia Spesifik \\
\hline $\begin{array}{l}\text { 1. Ir melihat proses make-up penganten } \\
\text { 2. Ir melihat proses make-up ibu di salon }\end{array}$ \\
\hline Tahap Pertengahan Mengatasi Anak Fobia Spesifik \\
\hline 3. Orang tua memajang foto pernikahan (ukuran besar) di rumah \\
\hline Tahap Akhir Mengatasi Anak Fobia Spesifik \\
\hline $\begin{array}{l}\text { 4. Orang tua (ibu) menginformasikan banyak makanan di resepsi } \\
\text { 5. Ibu menyatakan makanan di resepsi enak dan banyak }\end{array}$ \\
\hline
\end{tabular}

Pada Kesadaran Orang tua pada Masalah Anak Fobia Spesifik, Jeng dan Wik memiliki jenjang pendidikan S1 - mengonsumsi bacaan (majalah) atau program acara (televisi) yang informatif dan mengandung unsur pendidikan. Sementara Rah dan Is (orang tua Ir, dan Del) cenderung mengonsumsi acara hiburan keduanya tidak mengenyam pendidikan S1.

Ardianto, Komala, dan Karlinah (2007) menyebutkan bahwa The Social Categories Theory berangkat dari sebuah kenyataan bahwa anggota masyarakat dikelompokkan berdasarkan kesamaan kategori, seperti: ras, agama, kewarganegaraan, jenis kelamin, usia, tingkat pendidikan, pekerjaan, penghasilan, dan lain-lain, dimana pada tiap-tiap kategori akan ditemukan karakteristik yang sama. Anak-anak menyukai radio Kids $F M$; remaja menyukai radio OZ, Ardan, Prambors, 99ers, dan lainlain; wanita dewasa menyukai radio Female dan Sky $F M$ - khalayak dari satu kategori yang sama biasanya menyukai pesan yang sama dan seringkali mereka memberikan respons yang relative sama.

Yang menarik adalah yang terjadi pada $\mathrm{Na}$ (orang tua Nar) - tidak mengenyam pendidikan S1, tetapi menyadari bahwa Nar terkena fobia, meski tidak mengerti arti fobia. Disini Na hanya meyakini yang disampaikan orang medis $(\mathrm{Ca}$ - kerabat Na seorang dokter) - berlaku teori penggabungan informasi.

Kelima orang tua anak fobia spesifik tersebut tidak ada yang memahami fobia secara mendalam. Wik dan Jeng hanya mengerti istilah fobia ketika mengonsumsi media massa - majalah (sebuah artikel), televisi (program acara kesehatan) yang fokus membahas fobia dengan durasi (televisi) dan jumlah halaman (majalah) terbatas.

Rakhmat (1998) menyebutkan bahwa media massa - surat kabar, majalah, radio, televisi, dan film merupakan media yang memiliki ciri

\section{Tabel 7 Tahapan Metode Orang Tua Adel (Fobia Silverman)}

\begin{tabular}{|c|}
\hline Tahapan Metode \\
\hline Tahap Awal Mengatasi Anak Fobia Spesifik \\
\hline $\begin{array}{l}\text { 1. Orang tua membeli spidol perak; orang tua (ibu) membeli pewarna kuku perak } \\
\text { 2. Kakak dan Del semangat - antusias mewarnai menggunakan spidol perak; kakak dan Del } \\
\text { semangat - antusias mewarnai kuku dengan pewarna kuku perak }\end{array}$ \\
\hline Tahap Pertengahan Mengatasi Anak Fobia Spesifik \\
\hline $\begin{array}{l}\text { 3. Ibu membeli boneka plastik } \\
\text { 4. Kakak dan Del semangat - antusias mewarnai boneka plastik dengan warna perak } \\
\text { 5. Kakak menginformasikan pada Del bahwa boneka-boneka plastik tersebut seperti orang- } \\
\text { orang di jalan (silverman), dan Del tidak takut }\end{array}$ \\
\hline Tahap Akhir Mengatasi Anak Fobia Spesifik \\
\hline $\begin{array}{l}\text { 6. Ibu membawa boneka-boneka plastik tersebut ke dalam mobil saat akan bepergian } \\
\text { 7. Ibu menyimpan boneka-boneka plastik tersebut diatas dashboard mobil } \\
\text { 8. Ibu membawa boneka plastik dan spidol perak saat akan bepergian (bermain di dalam } \\
\text { mobil) }\end{array}$ \\
\hline
\end{tabular}


mengutamakan unsur isi pada pesan; informasi disusun berdasarkan sistem tertentu dan ditulis dengan menggunakan tanda-tanda baca serta pembagian paragraph yang tertib, urutan informasi dibuat runut, dan penggunaan bahasa mudah dimengerti oleh semua pihak.

Khalayak dalam media massa heterogen dan anonim - penyajian harus disesuaikan dengan keberadaan khalayak menghasilkan salah satu efek isi pesan - kognitif, efek prososial kognitif - keberadaan media massa telah memberikan manfaat bagi masyarakat, menanamkan pengetahuan, menjadi sumber informasi dan rujukan bagi khalayaknya.

Keduanya terkena efek prososial kognitif media massa - Wik dan Jeng mampu mengidentifikasi masalah fobia dengan tepat, meski tidak detail dan rinci seperti seorang psikolog atau buku-buku teks psikologi (Wik dan Jeng tidak berusaha mencari informasi tambahan terkait fobia spesifik pada anak).

Media massa telah menarik perhatian Jeng - menceritakan pengalaman fobia vokalis band favorit Jeng - menjadikan Jeng mengingat dan mengerti istilah fobia (artikel majalah berfokus pada objek fobia).

Media massa telah menampilkan pengalaman serupa dengan pengalaman Wik - menjadikan Wik memperhatikan tayangan - menyimpulkan isi dari tayangan (tayangan televisi berfokus pada gejala fobia), dan mengerti istilah fobia. Bila yang disajikan televisi itu ternyata juga cocok dengan apa yang disaksikan pemirsanya pada lingkungannya, daya penanaman ideologi dari televisi ini makin kuat. Ini disebut Gerbner sebagai "resonance" (Rakhmat, 1998: 250).

Pada tahapan metode orang tua mengatasi anak fobia spesifik, $\mathrm{Na}$, Rah, dan Is menggunakan teknik komunikasi terapeutik verbal, sementara Wik dan Jeng menggunakan teknik komunikasi terapeutik nonverbal - menghasilkan tiga model komunikasi terapeutik: (1) Vicarious experience models - terjadi pada treatment yang dilakukan Wik dan Jeng, menggunakan media wakilan (videoclip dan buku cerita), (2) Noticeable experience models - terjadi pada treatment yang dilakukan $\mathrm{Na}$ dan Rah, menggunakan media asli (sesungguhnya), dan (3) Playing experience models - terjadi pada treatment yang dilakukan Is, menggunakan media permainan.

Kelimanya menyertakan unsur-unsur pengalaman langsung, peneguhan, penggunaan isyarat verbal dan nonverbal dalam treatmentnya - membantu anak fobia spesifik mengubah persepsinya terhadap objek yang ditakutinya.

Seperti yang terjadi pada Gel, Wik berbicara pada Nai (adik Gel) bahwa badut adalah boneka orang - mengganti kata badut dengan boneka orang - mengubah persepsi Gel terhadap badut, teori interaksionisme simbolik. Yang menurut Rakhmat (1998) bahwa persepsi ialah memberikan makna pada stimuli inderawi.

$\mathrm{Na}$ menyebut dokter dengan sebutan teman Teh Ca (dokter muda) dan guru Teh Ca (dokter senior). Hal ini dapat mengubah persepsi Nar terhadap dokter. Pesan verbal teman Teh $\mathrm{Ca}$, guru Teh Ca dimaknai lebih bersahabat - dekat oleh Nar-konotasi positif, teori interaksionisme simbolik.

Wik dan Jeng melakukan peneguhan dengan mengungkapkan bahwa "Wik dapat seperti badut jika memakai kostum badut"; Jeng mengucap "Alhamdulillah, hebat" (melihat polisi mengatur jalan) - peneguhan. Rakhmat (1998) menjelaskan bahwa peneguhan adalah proses memperteguh respon yang baru dengan mengasosiasikannya pada stimuli tertentu berkali-kali. Sementara Rah dan Na mengalami kejadian tertentu - menyebabkan anak fobia spesifik tidak takut dengan objek dokter dan penganten.

Rakhmat (1998) menyebutkan bahwa pengalaman mempengaruhi kecepatan persepsi. Pengalaman tidak selalu lewat proses belajar formal, tetapi akan bertambah melalui rangkaian peritiwa yang pernah dihadapi - teori belajar; tidak mempersoalkan manusia baik atau jelek, rasional atau emosional; perilaku manusia dikendalikan oleh faktor-faktor lingkungan; perilaku adalah hasil pengalaman (paling berpengaruh dalam membentuk perilaku) teori belajar.

Lalu $\mathrm{Na}$ dan Is menggunakan isyarat nonverbal - pakaian warna putih dan boneka plastik yang diwarnai perak. Hal ini dapat mengubah persepsi anak fobia spesifik terhadap objek yang ditakutinya - teori interaksionisme simbolik.

Griffin (2003) menyebut bahwa setiap isyarat nonverbal (seperti body language, gerak fisik, baju, status, dll) dan pesan verbal (seperti kata-kata, suara, dll) yang dimaknai berdasarkan kesepakatan bersama oleh semua pihak yang terlibat dalam suatu interaksi merupakan satu bentuk simbol yang mempunyai arti yang 
sangat penting (a significant symbol).

Berdasar hal tersebut dapat diketahui bahwa kelima orang tua anak fobia spesifik ini - Wik, Na, Jeng, Rah, dan Is memiliki alasan sendiri dalam menggunakan teknik komunikasi terapeutik verbal dan nonverbalnya.

Wik dan Jeng menggunakan videoclip lagu dan buku cerita memiliki alasan dengan teknik komunikasi terapeutik nonverbalnya. Jeng mencari sesuatu yang ringan, sederhana, dan tidak membebani Gem - menjadikan Gem tertarik mendengar cerita Jeng, sementara Wik mengutamakan rasa empati dalam treatmentnya.

Rakhmat (1998) menjelaskan bahwa berempati tidak sekedar menempatkan diri kita pada posisi orang lain, tetapi kita ikut serta secara emosional dan intelektual dalam pengalaman orang lain. Berempati artinya membayangkan diri kita pada kejadian yang menimpa orang lain; berusaha melihat seperti orang lain melihat, merasakan seperti orang lain merasakannya.

Keduanya - Wik dan Jeng fokus dengan teknik komunikasi terapeutik nonverbalnya, disamping mereka menambah teknik komunikasi terapeutik verbal dengan melakukan treatment saat anak bertemu dengan objek yang ditakutinya (pengalaman langsung) - menjadikan anak yakin, percaya dengan apa yang sudah disampaikan ibu sebelumnya. Sementara $\mathrm{Na}$, Rah, dan Is menggunakan pengalaman langsung dan kegiatan mewarnai dalam treatmentnya (teknik komunikasi terapeutik verbal) - coba-coba dan penasaran.

Ketiga orang tua (ibu) anak fobia spesifik ini - Na, Rah, dan Is, cenderung menggunakan teknik komunikasi terapeutik verbal dalam treatmentnya, disamping ada yang menambahnya dengan teknik komunikasi terapeutik nonverbal - Rah memajang foto pernikahan berukuran besar dengan alasan tertarik untuk memajang foto tersebut. Kelima orang tua anak fobia spesifik ini memiliki alasan yang beragam dengan treatment yang dilakukannya.

\section{SIMPULAN}

Simpulan yang diambil dari penelitian ini adalah bahwa: (1) Kesadaran orang tua terhadap masalah fobia spesifik dapat ditimbulkan oleh konsumsi media massa yang relevan serta komunikasi antarpribadi dengan orang yang dianggap kredibel, (2) Cara orang tua mengidentifikasi anak terkena fobia spesifik dapat dilihat dari pemerolehan informasi melalui media massa serta pengalaman orang tua melakukan komunikasi antarpribadi dengan orang medis, (3) Tahapan metode yang digunakan orang tua untuk mengatasi anak fobia spesifik dapat dilihat dari teknik komunikasi terapeutik verbal - dilakukan secara tidak rutin dan langsung, menghasilkan noticeable experience models (media asli - sesungguhnya) dan playing experience models (media permainan), sementara teknik komunikas terapeutik nonverbal - menghasilkan vicarious experience models (media wakilan - videoclip dan buku cerita, rutin, tidak langsung), dan (4) Alasan orang tua terkait teknik komunikasi terapeutik yang dilakukannya - berfokus pada anak (mengedepankan rasa empati mencari sesuatu yang disukai anak, mencari sesuatu yang dapat menarik perhatian anak) dan berfokus pada pengalaman pribadi orang tua (mengedepankan komunikasi antarpribadi orang tua dengan rekannya serta pengalaman orang tua sendiri terkait objek fobia anak)

Sedangkan saran yang penulis ajukan yaitu: (1) Kesadaran orang tua harus ditumbuhkan dengan membaca atau menonton programprogram televisi yang bermanfaat serta banyak berhubungan dengan orang-orang yang dapat memberi nilai lebih - pengetahuan dan pengalaman terkait tumbuh kembang anak, (2) Identifikasi yang dilakukan orang tua berdasar pemerolehan informasi melalui media massa atau pengalaman komunikasi antarpribadi dengan orang medis dan non medis sebaiknya diimbangi dengan buku-buku parenting terkait usia anak - informasi yang diberikan menjadi lebih jelas dan detail, (3) Memilih treatment treatment yang sesuai dengan hobi, kesukaan anak - mempermudah orang tua menentukan jenis treatment, membuat anak mudah terlibat dalam proses treatment. Disamping peran seluruh anggota keluarga - ayah, kakak, adik dibutuhkan untuk memperkuat treatment yang telah dilakukan ibu, dan (4) Alasan orang tua anak fobia spesifik dalam melakukan teknik komunikasi terapeutik seharusnya mengedepankan alasan empati - kepentingan anak, apapun yang dilakukan orang tua dapat diterima dengan mudah dan dimengerti oleh anak - komunikasi. 


\section{DAFTAR PUSTAKA}

Ardianto, E., Komala, L. dan Karlinah, S. (2007). Komunikasi massa suatu pengantar Edisi Revisi. Bandung: Simbiosa Rekatama Media.

Ardianto, Elvinaro., Q-Anees, Bambang. 2007. Filsafat Ilmu Komunikasi. Bandung: Simbiosa Rekatama Media.

Bener, A., Ghuloum S., \& Dafeeah, E. E. (2011). Prevalence of common phobias and their socio-demographic correlates in children and adolescents in a traditional developing society. African Journal of Psychiatry, 14, 140-145

Benner, D.G.(ed) \& Hill, P.C.(ed) (1999). Baker encyclopedia of psychology and counseling. Michigan: Baker Academic.

Creswell, J. W. (1997). Qualitative inquiry and research design: choosing among five traditions. California: Sage Publications, Inc.

Denzim, Norman K., Lincoln. 1994. Handbook of Qualitative Research. California: Sage Publication, Inc.

Duvall, Evelyn M. 1977. Marriage and Family Development. New York: J.B. Lippincott Company Philadelpia.

Effendy, Onong Uchjana. 1989. Kamus Komunikasi. Bandung: Mandar Maju.

Effendy, Onong Uchjana. 2000. Ilmu Teori dan Filsafat Komunikasi. Bandung: PT.Rosdakarya.

Friedman, Marilyn M. 1998. Keperawatan Keluarga: Teori dan Praktik. Jakarta: EGC.

Ginsburg, G.S. \& Walkup, J.T. (2004). Phobic and anxiety disorders in children and adolescents. Dalam Ollendick, T.H. \& March, J.S. "Specific phobia". New York: Oxford University Press.

Griffin, E. A. (2003). A first look at communication theory. 5th Edition. New York: McGraw-Hill.

Hawari, D. (2007). Pendekatan holistik pada gangguan jiwa, Skizofrenia. Jakarta: FKUI

Kam. 2001. Kamus Besar Bahasa Indonesia. Edisi ke-3 - Cetakan 1. Jakarta: Balai Pustaka.

Kaplan, Harold I., Sadock, Benjamin J, Grebb, Jack A. 2002. Sinopsis Psikiatri Ilmu Pengetahuan Psiatri Klinis. Jakarta: Binarupa Aksara.
Kartono, K. (2000). Hygiene mental. Bandung: Mandar Maju.

Lichtenstein, P., \& Annas, P. (2000). Heritability and prevalence of specific fears and phobias in childhood. Journal of Child Psychology and Psychiatry, 41, 927-937

Littlejohn, Stephen W dan Karen A, Foss. 2009. Teori Komunikasi Edisi 9. Jakarta: Salemba Humanika.

Mahendratto, B. (2007). Cara orang tua mengatasi anak saat mogok sekolah. Jakarta: Grasindo.

Maramis, W.F. (1994). Catatan ilmu kedokteran jiwa. Surabaya: Airlangga University Press.

Moleong, L. J. (1999). Metode penelitian kualitatif. Bandung: Remaja Rosdakarya.

Mulyana, D. \& Solatun. (2007). Metode penelitian komunikasi. Bandung: Remaja Rosdakarya.

Nurjanah, I. (2005). Dasar-dasar komunikasi bagi perawat. Yogyakarta: Moco Medika.

Purwanto, H. (1994). Komunikasi untuk perawat. Jakarta: EGC.

Rafy, Y. A. (2004). Kamus ungkapan psikologi. Jakarta: Restu Agung.

Rakhmat, J. (1998). Psikologi komunikasi. Bandung: Remaja Rosdakarya.

Sondang, E. (2010) Menghapus fobia. Diakses dari http://m.tabloidnova.com/layout/set/ print/Nova/Keluarga/Anak/MenghapusFobia

Supartini, Yupi. 2004. Buku Ajar Konsep Dasar Keperawatan Anak. Jakarta: Penerbit Buku Kedokteran EGC.

Suryani. (2005). Komunikasi terapeutik: teori dan praktik. Jakarta: EGC.

Titisan, M. (2011). Metode maternal reflektif dalam komunikasi terapeutik (studi kasus komunikasi terapeutik pada anak tunarungu di SLB-B). FISIPOL (Ilmu Komunikasi), Vol 7, No 6

Ward, Ivan. 2003. Fobia.Yogyakarta: Pohon Sukma.

West, Richard., Lynn H. Turner. 2008. Pengantar Teori Komunikasi: Analisis dan Aplikasi. Buku 1 edisi ke-3. Terjemahan. Maria Natalia Damayanti Maer. Jakarta: Salemba Humanika.

Yihun, A., Anand, P., \& Abebe, F. (2011). Psychological intervention of murophobia. Internet Journal of Medical Update, 6(2), 61-64. 